\title{
Charity as an expression of creative love ${ }^{1}$
}

\author{
Dr. Robert Nęcek \\ Social Sciences Department \\ The Pontifical University of John Paul II, Krakow
}

\section{Introduction}

An appeal to practice charity everyday is become one of the priorities in social teaching of the Catholic Church. This charity became clearly visible in the life and actions of St. Józef Sebastian Pelczar. The saint bishop was a great advocate of charity, as a pastor and professor. He noticed - as emphasized by Benedict XVI - ,the need for the presence of Catholicism in the modern world culture and society, and because of that, with all his enlightened bumanism and goodness, be sacrificed bimself to Christian, ethical and professional education of new generations " . However, charity is sometimes confused with mercy and compassion. Therefore, first we will show the differences between those synonyms. Without doubt, mercy is associated with sensitivity concerning a specific shortage, specific suffering and specific human poverty ${ }^{2}$. It is an important experience which is an emotional shock that not only wrings tears but stimulates specific help. It is a result of being touched by poverty ${ }^{3}$.

If mercy takes the form of concrete help, than it becomes clearly involved and takes the shortest route to remove and alleviate the pain, suffering and poverty ${ }^{4}$. He may not understand, but still wants to help. On the other hand, mercy - which is a temporary and passing feeling - "lasts about as long as the view of buman poverty lasts. Escaping from the view,

\footnotetext{
${ }^{1}$ Lecture upon an invitation of Archbishop Zygmunt Zimowski, the President of the Pontifical Council for Pastoral Care of the Sick and Health Care Workers, Rome, 19 January, 2013.

2 BENEDYKT XVI. Wiarygodni głosiciele Ewangelii. Homilia podczas Mszy świętej kanonizacyjnej (21.10.2012). „L'Osservatore Romano” 12:2012 s. 24.

${ }^{3}$ Por. E. STANIEK. Mitosierdzie a prawda. Relatywizm, etyka sytuacyjna, lustracja. W: Wspótczesne oblicza miłosierdzia. Red. L. MATEJA. Kraków 2007 s. 11.

${ }^{4}$ Por. J. TISCHNER. Drogi i bezdroża mitosierdzia. Kraków 1999 s. 17.
} 
we run away from mercy" . Compassion may concern joyful things in human life, while charity concerns above all poverty and indigence. Therefore, "it is good when mercy leads to compassion, and compassion leads to charity. Only charity is the crown of love whose spores can be found in compassion and mercy" ${ }^{\prime \prime}$. In this context, the following will be discussed the general characteristics and determinants of charity with its basic principles.

\section{Charity - general characteristic}

The very concept of "charity" is a love that encourages one to have confidence and raises one from a fall ${ }^{7}$. It is a response, full of love, to material and spiritual evil that one encounters ${ }^{8}$. This means an attitude that allows one to understand that "love becomes charity when it can exceed a strict measure of justice, strict and sometimes too narrow".

Therefore, „charity, in its correct and full shape manifests itself as selfrespect, lifting up and bringing out goodness from under every layer present in the world and bumans $" 10$. This is because the person doing charity believes that everything is still there to save, that not everything is lost and that it is still possible to withdraw. This means that charity is a pain, but a pain of hope ${ }^{11}$. That pain of hope is well manifested in the story of the Pharisee and publican. The Pharisee is self-concentrated. He does not notice God, furthermore, he does not even need Him, because he can take care of his own business. The meeting between the Pharisee and God is devoid of any bond. Furthermore, a real bond with God would make acting difficult ${ }^{12}$. The Pharisee wrote his religiousness on paper, like musical scores. But he could not sing out his faith because it was not in his heart. Furthermore, in his heart there was no love, either ${ }^{13}$. But the publican sees himself and his life from the perspective of God's gift and God's goodness.

\footnotetext{
${ }_{5}^{5}$ J. TISCHNER. Drogi i bezdroża, p. 18.

6 ibid.

${ }^{7}$ Cf. JOHN PAUL II. Przekroczyć próg nadziei. 1995, Lublin p. 40.

${ }^{8}$ Cf. J. NAGÓRNY. Mitosierdzie. IN: JOHN PAUL II. Encyklopedia nauczania moralnego. Ed. J. NAGÓRNY, K. JEŻYNA. Radom 2005 p. 319.

${ }_{9}$ JOHN PAUL II. Dives in misericordia no. 5, Encyclical.

${ }^{10}$ ibid. no. 6.

11 Cf. J. TISCHNER. Drogi i bezdroża miłosierdzia. p. 22; R. NĘCEK. Miłosierdzie i solidarność w nauczaniu społecznym Kościoła. In: Współczesne oblicza miłosierdzia. Ed. L. MATEJA. 2007 Cracow, p. 46-47.

${ }^{12}$ Cf. BENEDICT XVI. Jesus of Nazareth. From the baptism in the Jordan to the transfiguration. T. I. 2007, Cracow p. 62.

${ }^{13}$ Cf. J. TISCHNER. Wiara ze słuchania. Kazania starosądeckie 1980-1992 Cracow, 2009 p. 169.
} 
By looking at God he realizes that he needs $\operatorname{Him}^{14}$. He realizes that "be needs charity, and this charity will prompt him that he should be charitable, through which he would become like God. He needs God and because he recognizes this through God's goodness, he becomes good himself. The ethos is not rejected here, it is liberated from constraining bonds of moralism and associated with a relation of love - with relation to God; only then does it become a true ethos"15. A true ethos is an attitude of humbleness, and humbleness is based on the truth. Humbleness "is not bumiliating oneself, travelling across the world and apologizing for your existence at every stage. Humbleness is about man knowing who be is, is aware of it and does not pretend that he is someone else"16. We can find a similarity in the Prodigal Son parable. Wasting one's own humanity becomes a pain of pains. The clement father sees his son's behaviour and complains because he is not able to help him ${ }^{17}$. His son's freedom becomes for him an unfortunate gift $^{18}$. Benedict XVI emphasizes that the son, being "completely free, in fact becomes a slave - a swineherd, and he would be happy if he could share their fodder. Being completely free, he became a miserable slave ${ }^{19}$. In this context, an open father becomes a harbinger of charity, and the reflective son enters the path of conversion. For this reason, charity is also called a gracious love, because it is able to restore man to himself ${ }^{20}$. The main determinants of restoring a human to himself are forgiveness and the provision of caritas.

\section{Forgiveness}

The primary determinant of charity is forgiveness. It is a path to reconciliation. However, in order for reconciliation to take place, forgiveness should be based on truth, which means that it cannot mean a resignation from the requirements of justice ${ }^{21}$. Love of course - as cardinal Ratzinger pointed out - "embraces an infinite readiness to forgive, but forgiveness also assumes that a sin is a sin. Forgiveness is healing, while the approval of evil would mean destruction, acceptation of an illness, which would mean consent to reject the other goodness" ${ }^{22}$. In this configuration, there is a close relationship between charity and justice, because forgiveness in the name

\footnotetext{
${ }^{14}$ Cf. BENEDICT XVI. Jesus of Nazareth. From the baptism in the Jordan to the transfiguration. T. I. Cracow 2007 p. 62-63.

15 TAMŻE, s. 63.

${ }_{17}^{16}$ J. TISCHNER. Wiara ze stuchania, p. 317.

${ }^{17}$ Cf. idem. Drogi i bezdroża, p. 48.

${ }^{18}$ Cf. idem. Nieszczęsny dar wolności. 1998, Cracow p. 10-11.

${ }^{19}$ BENEDICT XVI. Jesus of Nazareth. From the baptism to the transfiguration. T. I, p. 176.

${ }^{20}$ JOHN PAUL II. Dives in misericordia, Encyclical no. 14.

${ }^{21}$ Cf. ibid., no. 14; J. NAGÓRNY. Miłosierdzie, p. 325.

${ }^{22}$ J. RATZINGER. To look on Christ. Translation: J. MERECKI. 2005, Cracow, p. 84.
} 
of love in no way deprecates objective requirements of justice ${ }^{23}$. Its ultimate source is - as stated by St. Józef Sebastian Pelczar - in the Son of God, because therein the charity is bonded with justice ${ }^{24}$.

In this spirit, John Paul II pointed out that the purpose of forgiveness is properly understood justice, which demands that injustice and depravation should be repaired and compensated. The avalanche of depravation can be stopped - as stated by priest Tischner - not only by the depraver, but "also by its witnesses. If someone witnessed an avalanche and was indifferent to it, he would probably have to attach a stone to his own neck" 25 . The point is that forgiveness does not mean absolution. On the contrary, it is a confirmation of guilt, because one is forgiven when he is guilty. But forgiveness does not purify the culprit, but it purifies the victim from the will of revenge. ${ }^{26}$. So, cardinal Ratzinger was right in saying that "someone in a totalitarian system saved himself, and perhaps also bis position, at a price of betraying his friend and his convictions - thus, his soul. A true love can understand that, but it will not approve of such an act, considering something that is actually not good, to be good. Forgiveness has its own internal path: it is a bealing, that is, it requires a return to the truth. If this is not the case, forgiveness becomes consent to self-destruction, and in this way it stands in contradiction to the truth and love, ${ }^{, 27}$.

Therefore, "there is no contradiction between justice and forgiveness. Because forgiveness does not remove or lessen the neccesity to remedy the evil, but seeks to re-invite individuals and groups to a community and states to the community of nations ${ }^{28}$. It is true that guilt always provokes revenge. Furthermore, in this way, it multiplies a chain of subsequent offenses, pushing man into an enclosed labyrinth of hatred. Meanwhile, the guilt can be removed not by revenge and vengeance, but by forgiveness ${ }^{29}$. For this reason, this is no longer an absolute demand to compensate for injustice, but to open to the person who is being forgiven. Then - as Pope

${ }^{23}$ Cf. J. NAGÓRNY. Postannictwo chrześcijan w świecie. 1998, Lublin p. 270.

${ }^{24}$ Por. J. S. PELCZAR. Życie Duchowe, czyli doskonatość chrześcijańska. T. 2 Kraków 2003 s. 353.

${ }^{25}$ J. TISCHNER. Ksiadz na manowcach. 2007, Cracow p. 132.

${ }^{26}$ Cf. idem. Nieszczęsny dar wolności. 1998, Cracow p. 113.

${ }^{27}$ J. RATZINGER. To look on Christ, p. 85. St. Augustine says: "there are many who know that they offended brothers but still don't want to say: <Forgive me $>$. They didn't ashamed to $\sin$, but ashamed to apologize; not ashamed of their wrongdoing, but they are ashamed of humbleness". AUGUSTINE. 211, 4 sermon, In: Ancient Christian texts. Sermons and homilies on the Lord and Virgin May Holidays. 1976, Lublin p. 173. St. Augustine pushes these people to the wall pointing out that they are not entitled to forgiveness.

${ }^{28}$ JOHN PAUL II. Address for the World Day of Peace. Forgive and you experience the peace (1997) no. 5.

${ }^{29}$ Cf. BENEDICT XVI. Jezus of Nazareth. From the Baptism in the Jordan to the Transfiguration. T. I, p. 138. 
John Paul II put it - "the deadly retaliation routine must make room for a liberating novelty of forgiveness. ${ }^{\text {B }}$.

In other words, "forgiveness costs one something - first, cost the one who forgives. ${ }^{\not 11}$. The idea is that evil does not exist on its own. Evil is an obvious lack of good. It appears in a healthy organism, constituting a shadow of the true reality ${ }^{32}$, while goodness has the nature of light. If you do not put obstacles in its way, it propagates by itself. Goodness comes from a deep faith. One doesn't need much, so that it can change much. ${ }^{33}$. Therefore, a request for forgiveness is more than just a moral appeal. It is in its deepest content - a Eucharistic prayer. ${ }^{34}$.

\section{Caritas}

The second determinant is the caritas, which is constantly needed, because there is no - as Benedict XVI emphasized in the Deus caritas est encyclical - such equitable economic and social order that would make love obsolete. ${ }^{35}$. Therefore, social sensitivity and concern for the marginalized becomes a testimony of God's love in man, becoming a contribution to overcome the temptations of violence and selfishness. ${ }^{36}$. There is an inseparable link "between the love of God and the love of thy neighbour. One requires the other in such a close manner that the statement about God's love becomes a lie if one becomes closed to one's neighbour or even gets to bate bim"37.

This means that a fundamental good that man must constantly develop is love. Without multiplying love, every other gift is meaningless. For this reason, only active love introduces man into God's perspective. ${ }^{38}$. In this context - by the fact of neighbourly love - Christianity reveals the name of God, who is love and at the same time makes man free. The essence "is to want. If you want, you can. And if you do not want, do not do

\footnotetext{
30 JOHN PAUL II. Address for the World Day of Peace. Forgive and you experience the peace (1997) no. 3.

${ }^{31}$ BENEDICT XVI. Jezus of Nazareth. From the Baptism in the Jordan to the Transfiguration. T. I, p. 140.

32 Cf. J. TISCHNER. Ksiadz na manowcach. 2007, Cracow p. 130.

${ }^{33}$ Cf. ibid. p. 132.

${ }^{34}$ BENEDICT XVI. Jezus of Nazareth. From the Baptism in the Jordan to the Transfiguration. T. I, p. 140.

35 Cf. idem. Deus caritas est encyclical, p. 28.

36 Por. JAN PAWEE II. Mitość najwspanialsza forma ewangelizacji. Przestanie na zakończenie Międzynarodowego Roku Wolontariatu (5.12.2001). W: TENŻE. Dzieła zebrane. T. V, s. 242.

${ }^{37}$ BENEDICT XVI. Deus caritas est, Encyclical no. 16.

${ }^{38}$ Cf. idem. Miłość jest dobrem, które każdy człowiek musi pomnażać (13.11.2011 Rome).

„L'Osservatore Romano” 1:2012 p. 54.
} 
it, because it is a threat of Pharisaism. A man who does without wanting, sooner or later will fall into Pharisee ambiguity." ${ }^{39}$. That is why one needs to "have the courage to be good. Because what is goodness in man, it is also bis immortality. "0. It is therefore about encouraging all forms of charity, because they are "a good opportunity to also meet people who do not yet know Christ or know him only partially. "11 . In this way, "Love grows through love..$^{\prime \prime 2}$. This means that love is necessary in thinking and "the presence of love in thinking is an expression of a magnanimous attitude. It is discernible: thinking gravitates towards knowing what there is, and to know what there is means allowing to be, and the same is contained in the essence of love - it also allows one to be." ${ }^{\prime 3}$.

On the other hand, for love to let man be fully magnanimous, commits one to continuously form the heart, because - as Benedict XVI teaches - "you cannot promote shaping the world in a human manner, by temporarily refusing to act bumanely. " ${ }^{44}$. Heart formation also requires that one should expand one's professional competence. The idea is to be able to help and to be well prepared for helping. ${ }^{45}$. Therefore caritas - as Archbishop Robert Zollitsch rightly noticed - is an expression of not only support, but, above all, the reality introducing one into the world of faith in Christ. ${ }^{46}$.

So what is actually caritas? Well, caritas is a specific response to an equally specific difficult situation in which man was found. This is a charitable ministry of the Church, which has always been the most convincing form of neighbourly love. ${ }^{47}$. In other words, you need <charity imagination> today, whose manifestation will not only be the effectiveness of $c a$ ritas ministry, but "the ability to be a neighbour to a suffering human and

\footnotetext{
${ }^{39}$ J. TISCHNER. Faith from listening. Sermons from Stary Sącz 1980-1992, p. 347.

40 ibid. p. 196.

${ }^{41}$ BENEDICT XVI. Świadkowie ewangelicznej miłości. Do Papieskiej Rady <Cor Unum> (29.02.2008). „L'Osservatore Romano” 4:2008 p. 31.

42 idem. Deus caritas est, Encyclical no. 18.

43 J. TISCHNER. Ksiądz na manowcach. Cracow 2007 p. 107; A. JĘDRZEJEWSKI. Społeczny wymiar działalności charytatywnej Kościoła. „Society” 6:2007 p. 824-825.

${ }^{44}$ BENEDICT XVI. Deus caritas est, Encyclical no. 31.

${ }^{45}$ Cf. ibidem.

46 Archbishop Robert Zollitsch - in the context of Caritas housework (?) - said: „Caritas steht nich nur fur Nächstenliebe, Hilfe und Solidarität. Caritas steht für Die entscheidenden Werte, die aus dem Glauben an Jesus Christus erwachsen und von denen unsere Gesellschaft lebt. Hier leistet die Kirche, hier leisten wir Christen einen unschätzbaren Wert für unser Zusammenleben“. R. ZOLLITSCH. Heilige Messe auf dem City-Airport. In: Apostolische Reise Seiner Heiligkeit Papst Benedikt XVI. nach Berlin, Erfurt und Freiburg (22-25. September 2011). Predigten, Ansprachen und Grußworte. Bonn 2011 p. 131.

${ }^{47}$ Por. R. NĘCEK. Miłosierdzie i solidarność w nauczaniu społecznym Kościoła, s. 47.
} 
sympathise with him." ${ }^{48}$. That is why you need to - as St. Józef Sebastian Pelczar wrote - see the people's pain at a close range, learn to look at their tears and blend your own tears with theirs. ${ }^{49}$. In this context, Benedict XVI - said in Lagiewniki, that the hands of supporters in the name of charity "are an extension of God's hands." ${ }^{50}$. The ministry of Caritas, in order to enjoy esteem, must be free and independent from ideology and political parties. ${ }^{51}$. For this reason, the Holy Father Benedict XVI noted that the development of a better world becomes real only when we act good "bere" and "now", regardless of changing party coalitions or raging ideologies. Christian program - a "program of the Good Samaritan, the program of Jesus - it's a heart that sees. This heart sees where love is needed and acts accordingly. ${ }^{, 52}$.

Providing Caritas, the Church reminds that it can not be a means of proselytism $^{\mathrm{fn}^{\mathrm{g}}}$, because love is not selfish, it is a gift. A gift that assumes the possibility to take it back one day it is not a real gift. So love cannot be practiced in order to achieve other benefits. ${ }^{53}$. Thus, everyone who "practices Caritas in the name of the Church will never seek to impose the Church faith on others. He knows that love in its purity and impartiality is the best testimony of God" ${ }^{\text {,54 }}$.

The responsibility for carrying out works of charity is borne by the Bishop Ordinarius. He appoints his co-workers - clerical and lay - so that, through their activities charitable life of the diocese could be stimulated. It should be noted that the staff of each catholic charity organization are committed to cooperate with the Church ${ }^{55}$. A testimony of such communication makes preaching Christ to the world more trustworthy and brings

\footnotetext{
${ }^{48}$ JOHN PAUL II. Novo Millennio Ineunte, Aphostolic Letter, no. 50.

49 Cf. J. S. PELCZAR. blessed Józef Sebastian Pelczar. Speeches and sermons 1877-1899. T. VII. Cracow, 1998 p. 131.

${ }^{50}$ Benedict XVI, Nawiedzenie Sanktuarium Bożego Miłosierdzia, Cracow - Łagiewniki (27 may 2007). In: Pielgrzymka Benedykta XVI do Polski (25-28 maja 2006., Przemówienia i homilie. 2006, Cracow p. 60.

51 Cf. BENEDICT XVI. Deus caritas est, encyclical, np. 31. The social teaching of the Church's ideology is understood as "a team of views on man, society, property and state, assimilated by broader social mass which constitute a base to seek concrete socio-political solutions." W. PIWOWARSKI. ABC of Catholic Social Doctrine, Legnica 1998, p. 98. However, the party is organized social groups, which have important, co-decision functions in the political system. The very name suggests that the word "party" means a part of a whole. Cf. W. PIWOWARSKI Dictionary of Catholic Social Teaching. Warszawa 1993 p. 127.

${ }^{52}$ BENEDICT XVI. Deus caritas est, Encyclical no. 31.

53 Por. R. NĘCEK. Miłosierdzie i solidarność w nauczaniu społecznym Kościoła, s. 49.

${ }^{54}$ BENEDICT XVI. Deus caritas est, Encyclical no. 31.

${ }^{55}$ Cf. ibid. no. 32-33.
} 
the provider and the receiver of charity closer to each other ${ }^{56}$. Additionally, a charity organization in collaboration with the Church is important for two reasons - the first is a Christians nadveté, which was used by greedy persons who more than once were capable of working, but did not work. One cannot require special wisdom from everyone. Meanwhile, the cooperation with the Church eliminated that kind of nadveté. However, the second reason was the issue of human dignity. The idea is to provide assistance without humiliating a person and not to make the charity recipient dependant on the provider. ${ }^{57}$.

\section{Rules for the implementation of charity deeds}

Implementation of charity deeds shall be within the limits of the rules developed by Christians over centuries. They have an ethical and social dimension, and constitute an intellectual order to create a sense of common values as a means necessary to achieve personal objectives. In addition, they direct people to take certain actions in certain situations. ${ }^{58}$. Charity the realization of creative love, which is why charity deeds are subject to an order of love. In other words, charity is closely associated with the ethics of responsibility, which becomes the ethics of conscience, and my conscience "tells me that I can not leave the other person with their problems, troubles, with their helplessness. I can not accept the principle: let everyone cope on their own, and if they cannot manage, it's their business. This rule authorizes an individual (group) selfishness. According to it, the other person could not exist as long as he/she does not serve my interests" ${ }^{59}$. In this context, the principles of charity are worth reminding.

\section{* principles of charity}

There are seven basic principles in the implementation of charity deeds:

$<$ charity applies to every Christian, as everyone can share their bread with someone who has nothing. Shifting responsibility onto the rich proves the lack of understanding of the issue and closing oneself to thy neighbour.

\footnotetext{
${ }^{56}$ Cf. Benedict XVI. Spotkanie ekumeniczne. Kościół luterański św. Trójcy (25 maja 2006). In: Pielgrzymka Benedykta XVI do Polski (25-28 maja 2006). Przemówienia i homilie. 2006, Cracow p. 23.

57 Cf. E. STANIEK. Bądźcie miłosierni jak miłosierny jest Ojciec wasz. XXIII Piesza Pielgrzymka Krakowska do Częstochowy (6-11.sierpnia 2003). Kraków 2003 s. 46; R. NĘCEK. Miłosierdzie i solidarność w nauczaniu społecznym Kościoła, s. 50.

${ }^{58}$ W. PIWOWARSKI. ABC of Catholic Social Teaching. 1998, Legnica p. 65.

${ }^{59}$ A. SZWED. Solidarity today. In: Człowiek Wobec wartości. Red. J. JAGIEŁEO, W. ZUZIAK. Kraków 2006 s. 65.
} 
$<$ never refuse help. Assistance always should be given. If I cannot do it by myself, then I'll ask somebody for help. It is worth noting that the "breakdowns among the righteous are always remorse of the community to which they belong. In the Church, it should not be happening",60. For this reason, Benedict XVI teaches that generosity in convictions and in action is possible only where there is a living faith, stimulating for resignation and responsibility for the neighbour and the whole community ${ }^{61}$.

$<$ charity must be wise. This means that you need to know how the money will be used and how it will be deposited. Do not encourage drug abuse, drunkenness and laziness. Christianity can not be identified with nadveté, but with wisdom and responsibility. The point is that paying attention to one's neighbour is associated with the desire of their good in every way - physical, moral and spirituat, ${ }^{62}$, and sponging is not such good.

$<$ When someone asks for bread, you should give it to him, but if he ask for money, you should check how far he really needs it.

$<$ real poverty is concealed. It never manifests itself. Only in the last resort it will reach out for help. Poor people usually need to be sought, and then discreetly helped. An example would be not only the Church Caritas, but also the "Noble Box" action initiated by priest Jacek Stryczka . In this project, there is a wise and clever search for the poor and the rich, while the latter helps the poor. Volunteers from the "Noble Box" wrote down seven criteria facilitating a realistic assessment of the situation of respondents - an illness of a child, when there is a need to take constant care, an accident, like a flood, fire or sudden death of a loved one, causing a rapid deterioration in the financial situation of the family, large families, or families with more than four children, single parenthood, indicating the need to maintain the family and lack of job opportunities, illness and disability, involuntary poverty inherited from generation to generation $^{63}$.

$<$ charity has a religious value, as it is a testament to the words of Christ: "Whatever you did for one of these least brothers of mine, you did for me."

\footnotetext{
${ }^{60}$ E. STANIEK. Bądźcie miłosierni jak miłosierny jest Ojciec wasz, s. 55.

${ }^{61}$ Cf. BENEDICT XVI. Jezus of Nazareth. From the Baptism in the Jordan to the Transfiguration. T. I, p. 75.

62 idem. Praktykowanie miłości bliźniego jest udziałem w nowej ewangelizacji. Przemówienie do członków Koła św. Piotra z okazji przekazania <obola> (24.02.2012).

„L'Osservatore Romano” 4:2012 p. 37.

${ }^{63}$ Cf. R. NĘCEK and others. Bitwa o Kościót. 2011, Cracow p. 57.

${ }^{63}$ Cf. E. STANIEK. Bądźcie mitosierni jak mitosierny jest Ojciec wasz, p. 56.
} 
$<$ finally, charity is closely linked to the altar, as in the early centuries various gifts were collected in baskets and distributed at the end of the Eucharist to the most needy ${ }^{64}$.

\section{Conclusion}

Summing up, it is clear that the implementation of the charity principle is the foundation of the Church's predictions and activities. It is a revelation of hope that life has not been lost; what's more, everything can be saved. Expression of charity are - forgiveness and caritas provision. The implementation of charity shall take place with a view to specific rules necessary for the completion of the ministry of love on a daily basis in an efficient and responsible manner.

\section{References}

BENEDICT XVI, Wiarygodni głosiciele Ewangelii. Homilia podczas Mszy świętej kanonizacyjnej (21.10.2012). „L'Osservatore Romano” 12:2012 s. 24 .

BENEDICT XVI, Świadkowie ewangelicznej miłości. Do Papieskiej Rady $<$ Cor Unum> (29.02.2008). „L'Osservatore Romano” 4:2008 p. 31.

BENEDICT XVI, Praktykowanie miłości bliźniego jest udziałem w nowej ewangelizacji. Przemówienie do członków Koła św. Piotra z okazji przekazania <obola> (24.02.2012). „L`Osservatore Romano” 4:2012 p. 37.

BENEDICT XVI, Jesus of Nazareth. From the baptism in the Jordan to the transfiguration. T. I. Cracow 2007.

BENEDICT XVI, Nawiedzenie Sanktuarium Bożego Miłosierdzia, Cracow Łagiewniki (27 may 2006). In: Pielgrzymka Benedykta XVI do Polski (25-28 maja 2006., Przemówienia i homilie. Cracow 2006.

BENEDICT XVI, Deus caritas est encyclical.

JOHN PAUL II, Mitość najwspanialsza forma ewangelizacji. Przestanie na zakonczenie Międzynarodowego Roku Wolontariatu (5.12.2001). W: Tenże. Dzieła zebrane. T. V, s. 242.

JOHN PAUL II, Przekroczyć próg nadziei, Lublin1995.

JOHN PAUL II, Dives in misericordia, Encyclical.

JOHN PAUL II, Address for the World Day of Peace. Forgive and you experience the peace (1997).

JOHN PAUL II, Novo Millennio Ineunte, Aphostolic Letter.

JĘDRZEJEWSKI, A., Spoteczny wymiar dziatalności charytatywnej Kościoła. „Society” 6:2007 p. 824-827.

NAGÓRNY, J., Miłosierdzie. IN: John Paul II. Encyklopedia nauczania moralnego. Ed. J. Nagórny, K. Jeżyna. Radom 2005 p. 319. 
NAGÓRnY, J., Postannictwo chrześcijan w świecie, Lublin 1998.

NĘCEK, R., and others, Bitwa o Kościót. Kraków 2011.

NECEK, R., Solidarność w nauczaniu społecznym Kościoła. In: Współczesne oblicza miłosierdzia. Ed. L. Mateja. Kraków 2007 p. 4348.

PELCZAR, J. S., Życie Duchowe, czyli doskonatość chrześcijańska. T. 2 Kraków 2003.

PELCZAR, J. S., Blessed Józef Sebastian Pelczar. Speeches and sermons 1877-1899. T. VII. Cracow, 1998.

PIWOWARSKI, W., ABC of Catholic Social Doctrine, Legnica 1998.

PIWOWARSKI, W., Dictionary of Catholic Social Teaching, Warszawa 1993.

RATZINGER, J., To look on Christ. Translation: J. Merecki. Kraków 2005.

STANIEK, E., Bądźcie miłosierni jak miłosierny jest Ojciec wasz. XXIII Piesza Pielgrzymka Krakowska do Częstochowy (6-11.sierpnia 2003), Kraków 2003.

STANIEK, E., Miłosierdzie a prawda. Relatywizm, etyka sytuacyjna, lustracja. W: Wspótczesne oblicza mitosierdzia. Red. L. Mateja. Kraków 2007 s. 10-16.

SZWED, A., Solidarity today. In: Człowiek Wobec wartości. Red. J. Jagiełło, W. Zuziak. Kraków 2006 s. 65.

TISCHNER, J., Drogi i bezdroża miłosierdzia, Kraków 1999.

TISCHNER, J., Wiara ze słuchania. Kazania starosądeckie 1980-1992, Kraków 2009.

TISCHNER, J., Nieszczęsny dar wolności. Kraków 1998.

TISCHNER, J., Ksiądz na manowcach. Kraków 2007.

ZOLLITSCH, R., Heilige Messe auf dem City-Airport. In: Apostolische Reise Seiner Heiligkeit Papst Benedikt XVI. nach Berlin, Erfurt und Freiburg (22-25. September 2011). Predigten, Ansprachen und Grußworte. Bonn 2011 p. 131-136. 